\title{
Evaluasi Standar Peletakan Alat Pemadam Api Ringan (APAR) di Kantor BPBD Provinsi Sumatera Utara
}

\author{
Fauziah Nasution $^{1}$, Ayunda Syahfira ${ }^{1}$, Siti Kholijah ${ }^{1}$, Arfan Syahputra \\ Pulungan $^{1}$ \\ ${ }^{1}$ Fakultas Kesehatan Masyarakat, Universitas Islam Negeri Sumatera Utara \\ Corresponding author: JI IAIN No 1 Medan, Sumatera Utara. \\ E-mail : ayunda.syahfira@gmail.com
}

Riwayat Artikel

Diterima: 11 Mei 2021

Disetujui: 12 Desember 2021

Dipublikasi: 26 Desember 2021

Keywords

APAR, SOP, Office, BPBD

\begin{abstract}
APAR (Light Fire Extinguisher) is a device used to extinguish a fire or control a fire. The availability of fire extinguishers is very necessary to prevent fires because not all places can reach water easily and have enough water to extinguish fires. This type of research used in this research is qualitative research with a descriptive approach. In the research that has been carried out, the results show that the level of suitability of fire procedures is $80 \%$, where there are Standard Operating Procedures (SOP) that have not been fulfilled, such as early notification when a fire occurs. In addition, the APAR placement made at the $B P B D$ office of North Sumatra Province did not comply with the applicable standards. Based on observations, observations at the BPBD office of North Sumatra Province during the evaluation were that the placement of the APAR was not in accordance with applicable procedures or standards, because the placement of the APAR in buildings I and II was not according to standards. For this reason, it is necessary to evaluate the installation of $A P A R$ at the $B P B D$ PROV SU Office to facilitate handling in the event of a fire in the office area.
\end{abstract}

\section{PENDAHULUAN}

APAR (Alat Pemadam Api Ringan) merupakan sebuah alat yang digunakan untuk memadamkan api atau mengendalikan kebakaran kecil. Alat Pemadam Api Ringan (APAR) pada umumnya berbentuk tabung yang diisikan dengan bahan pemadam api yang bertekanan tinggi. Dalam Keselamatan dan Kesehatan Kerja (K3), APAR merupakan peralatan wajib yang harus dilengkapi oleh setiap instansi maupun perusahaan guna mencegah terjadinya kebakaran yang dapat mengancam keselamatan pekerja dan asset perusahaan itu sendiri. Pembangunan sebuah gedung harus memerhatikan nilai keselamatan terhadap semua ancaman bahaya yang dapat terjadi seperti bahaya kebakaran.

Berdasarkan UU No.1 Tahun 1970 tentang keselamatan kerja dimaksudkan dalam menentukan standar yang jelas untuk keselamatan kerja bagi seluruh karyawan sehingga 
mendapat perlindungan atas keselamatannya dalam melakukan pekerjaan untuk kesejahteraan hidup dan meningkatkan produksi dan produktivitas nasional. Pada bab III pasal 3 dijelaskan mengenai syarat-syarat keselamatan kerja yaitu mencegah, mengurangi dan memadamkan kebakaran-kebakaran. Serta terdapat keputusan menteri yang mengatur tentang ketenagakerjaan yaitu Keputusan Menteri Tenaga Kerja No. KEP.186/MEN/1999, Bab 1 pasal 2 berisi tentang unit penanggulangan kebakaran di tempat kerja yaitu pengurus/pengusaha wajib mencegah, mengurangi dan memadamkan kebakaran di tempat kerja dan dilaksanakan sesuai dengan peraturan yang berlaku.

Menurut Permen PU No. 26 Tahun 2008 Tentang Persyaratan Teknis Sistem Proteksi Kebakaran pada Bangunan Gedung dan Lingkungan, menjelaskan tentang standarisasi untuk masalah perlindungan kebakaran terhadap bangunan gedung dan lingkungan. Dijelaskan juga tentang syarat teknis untuk Alat Pemadam Api Ringan (APAR) pada bab V yang berisi tentang Sistem Proteksi Kebakaran Aktif. Peraturan Menteri Tenaga Kerja dan Transmigrasi No : Per.04/Men/1980 juga menjelaskan tentang Syarat-Syarat Pemasangan dan Pemeliharan Alat Pemadam Api Ringan yang berisikan tentang ketentuan standarisasi APAR di Indonesia yang harus di laksanakan. Dijelaskan juga pada peraturan di Amerika tentang APAR yang tertulis di NFPA 10 tahun 2002 tentang standar alat kebakaran portabel yang menjelaskan tentang standar-standar yang diharuskan untuk pemasangan dan pemeliharaan tentang APAR.

Ketersediaan APAR sangat diperlukan untuk mencegah kebakaran karena tidak semua tempat dapat menjangkau air dengan mudah dan memiliki air dalam jumlah yang cukup ketika memadamkan api, selain itu jika sudah terjadi kebakaran dengan api besar akan lebih sulit dipadamkan dan harus meminta bantuan pada petugas pemadam kebakaran padahal untuk menuju tempat terjadinya kebakaran juga perlu memakan waktu dan dikhawatirkan jika api tidak segera ditangani akan lebih cepat merambat serta membakar lebih banyak benda disekitarnya yang akan menimbulkan lebih banyak kerugian harta benda bahkan membahayakan nyawa bagi orang di sekelilingnya. Kebakaran adalah api yang tidak terkendali yang meluap dan menyebabkan kerugian. Kerugian yang ditimbulkan dari kebakaran yaitu kerugian jiwa, kerugian materi, menurunnya produktivitas, gangguan bisnis serta kerugian sosial (Ramli, 2010).

Kebakaran pada bangunan gedung dapat menimbulkan kerugian berupa korban jiwa, harta benda, terganggunya proses produksi barang dan jasa, kerusakan lingkungan dan terganggunya ketenangan masyarakat (Angela, 2006). Seiring meningkatnya ukuran dan kompleksitas bangunan gedung, sudah seharusnya pula diiringi dengan peningkatan perlindungan terhadap masyarakat. Penanganan kebakaran di gedung-gedung masih mengandalkan kesiapsiagaan dan peralatan dari pemadam kebakaran setempat. Kesiapsiagaan dari pemadam kebakaran gedung pun terkadang masih kurang memadai.

Penyediaan APAR di ruang tertutup maupun terbuka sangatlah penting apalagi tempat yang rawan atau berpotensi terjadi kebakaran. APAR sendiri merupakan suatu alat pemadam yang dapat dibawa dan digunakan oleh satu orang, beratnya berkisar antara 1 hingga 15kg, dan digunakan untuk memadamkan kebakaran tingkat awal (Teguh Hambudi, 2015).

Tanggap darurat kebakaran di gedung bertingkat tidak hanya mengandalkan sistem proteksi aktif seperti alat pemadam ringan (APAR), smoke detector juga springkler, namun 
diperlukan juga sistem proteksi pasif salah satunya dengan sarana penyelamat diri atau means of escape (MOE). Sarana penyelamat diri sangat penting karena prioritas utama pada saat kebakaran adalah menyelamatkan manusia yang berada di lokasi kejadian. Sebagian besar kematian pada saat terjadi kebakaran di gedung disebabkan oleh asap. Oleh karena itu sangat penting untuk menyiapkan rute aman menyelamatkan diri dari bahaya kebakaran atau asap.

Kantor BPBD Provinsi Sumatera Utara mempunyai dua gedung yang aktif digunakan oleh para karyawan dalam menjalani tugas hariannya. Masing-masing gedung memiliki 2 lantai dimana masing-masing gedung tersebut peletakan APAR nya belum sesuai dengan letak yang seharusnya. Hal ini dapat mengakibatkan kerugian yang sangat besar pada saat terjadi darurat kebakaran di gedung tersebut. Ditambah lagi belum adanya petugas khusus maupun karyawan yang terampil atau memiliki keahlian dibidang darurat kebakaran.

Berdasarkan uraian diatas perlu dilakukan sebuah usaha yang bertujuan untuk meminimalisir kerugian yang harus ditanggung akibat bahaya kebakaran. Yaitu dengan menganalisis peletakan dan kebutuhan APAR perlu diperhatikan kesesuaiannya dengan Peraturan Menteri Tenaga Kerja dan Transmigrasi No.4 Tahun 1980 Tentang Syarat Pemasangan dan Pemeliharaan Alat Pemadam Api Ringan.

\section{METODE}

Jenis penelitian yang digunakan adalah deskriptif bertujuan untuk menjelaskan fenomena suatu keadaan secara objektif. Responden utama dalam penelitian ini berjumlah 5 orang yaitu terdiri dari 1 orang dokter jaga Klinik Pratama BPBD Provinsi Sumatera Utara, 1 orang kepala bidang II (Peralatan dan Logistik), dan 1 orang kepala subbidang Pemberdayaan Masyarakat, dan 2 orang staff pekerja.

Penelitian ini dengan menggunakan metode survei deskriptif melalui pendekatan observasional dan wawancara. Pengukuran dan observasi dilakukan terhadap penerapan Alat Pemadam Api Ringan (APAR) di Kantor BPBD Provinsi Sumatera Utara untuk kemudian dibandingkan dengan peraturan dan standart yang berlaku. Sedangkan wawancara dilakukan dengan pedoman wawancara yang dibuat oleh peneliti.

\section{HASIL DAN PEMBAHASAN}

\section{Upaya Penanggulangan Kebakaran}

Berdasarkan hasil observasi yang telah dilakukan di gedung Kantor BPBD Provinsi Sumatera Utara didapatkan hasil bahwa Kantor BPBD Provinsi Sumatera Utara sudah memiliki sistem upaya penanggulangan kebakaran, meliputi penyediaan Alat Pemadam Api Ringan (APAR), tangga darurat, rambu-rambu keselamatan, prasarana penanggulangan kebakaran yang meliputi penyediaan sumber air untuk suplai hidran, adanya jalur evakuasi. 
Pencegahan dan penanggulangan serta penyelamatan diri dari bencana kebakaran adalah suatu rangkaian peristiwa yang mengancam dan mengganggu kehidupan dan penghidupan masyarakat yang disebabkan oleh kelalaian manusia maupun faktor lain, sehingga mengakibatkan timbulnya korban jiwa manusia, kerusakan lingkungan, kerugian harta benda serta dampak psikologis.

Sistem upaya penanggulangan kebakaran terdiri atas penyediaan APAR, hydrant, alarm kebakaran, tangga darurat, dan rambu-rambu keselamatan, prasarana penanggulangan kebakaran yang terdiri dari penyediaan sumber air untuk menyuplai hydrant, adanya berupa jalur evakuasi, serta prosedur-prosedur penanggulangan kebakaran yang meliputi tersedianya SOP kebakaran dan buku pedoman penangan bencana di gedung bertingkat.

\section{Prosedur Operasional Standar Kebakaran}

Berdasarkan hasil observasi yang telah dilakukan, prosedur operasional standar kebakaran berdasarkan Kepmen PU No. 11 tahun 2000 diketahui bahwa Kantor BPBD Provinsi Sumatera Utara telah mempunyai prosedur operasional standar kebakaran, yang disebut dengan Standar Prosedur Operasional (SPO) kebakaran. Tingkat kesesuaian prosedur kebakaran sebesar $80 \%$, dimana beberapa kriteria telah dipenuhi. Pada SPO kebakaran ini berisi langkah-langkah pemberitahuan awal kebakaran, pelaksanaan evakuasi dan pemeriksaan dan pemeliharaan peralatan proteksi kebakaran. Dari beberapa SPO yang telah dijabarkan di atas, terdapat Standar Prosedur Operasional (SPO) yang belum terpenuhi yaitu seperti pemberitahuan awal saat terjadi kebakaran.

Peningkatan kemajuan pembangunan gedung-gedung menyebabkan tingginya resiko terjadinya kebakaran. Penduduk yang semakin banyak, Pembangunan perkantoran, gedung dan perumahan, industri yang semakin berkembang menyebabkan kawasan-kawasan ini memiliki potensi besar untuk terjadinya kebakaran Dalam hal ini peran Dinas Pencegah dan Pemadam Kota Medan sangatlah diperlukan.

Berdasarkan Kepmen PU no. 11 tahun 2000 diketahui bahwa BPBD Provinsi Sumatera Utara telah sesuai dengan prosedur operasional standar kebakaran, yang disebut Standar Prosedur Operasional (SPO) kebakaran. Tingkat kesesuaian prosedur kebakaran sebesar $80 \%$, dimana seluruh kriteria telah dipenuhi. Pada SPO kebakaran ini berisi langkah-langkah pemberitahuan awal kebakaran, pelaksanaan evakuasi dan pemeriksaan dan pemeliharaan peralatan proteksi kebakaran. Dari beberapa SPO yang telah dijabarkan di atas, terdapat Standar Prosedur Operasional (SPO) yang belum terpenuhi yaitu seperti pemberitahuan awal saat terjadi kebakaran.

\section{Peletakan Alat Pemadam Api Ringan (APAR)}

Alat pemadam api ringan (APAR) yang ada di kantor BPBD Provinsi Sumatera Utara berisi gas cair yang merupakan turunan dari gas halon dan memiliki kapasitas $6 \mathrm{~kg}$ dan $7 \mathrm{~kg}$. Kelebihan APAR jenis gas cair adalah bersifat bersih tidak meninggalkan residu, tidak merusak lapisan ozon atau non halon non CFC, ramah lingkungan (clean agent) dan lebih cepat memadamkan api. Material tabung APAR tersebut terbuat dari bahan mild steel dan dilapisi dengan cat berwarna merah. Rating/kelas kebakaran yang dapat ditanggulangi yaitu kelas $\mathrm{A}, \mathrm{B}$ dan $\mathrm{C}$. Pemasangan APAR telah dilengkapi dengan tanda dan label cara penggunaan APAR. 
Berdasarkan hasil wawancara yang telah dilakukan oleh informan didapatkan hasil bahwa terdapat Alat Pemadam Api Ringan (APAR) di setiap gedung yang ada di BPBD Provinsi Sumatera Utara dan pemasangan serta peletakannya sudah disesuaikan dengan standar. Sedangkan pada hasil observasi ditemukan hasil bahwa Alat Pemadam Api Ringan (APAR) di setiap gedung yang ada di BPBD Provinsi Sumatera Utara berdasarkan Permenaker no. 4 tahun 1980 menunjukan bahwa tingkat kesesuaian APAR sebesar 66,67\%.

Keputusan Menteri Tenaga Kerja No. KEP.186/MEN/1999, Bab 1 pasal 2 berisi tentang unit penanggulangan kebakaran di tempat kerja yaitu pengurus / pengusaha wajib mencegah, mengurangi dan memadamkan kebakaran di tempat kerja dan dilaksanakan sesuai dengan peraturan yang berlaku.

Tanda dalam peletakan APAR juga sangat penting untuk kepentingan penanggulangan kebakaran, karena dengan adanya tanda letak APAR maka pekerja lebih mudah mengetahui letak APAR. Diketahui bahwa perusahaan belum sesuai dengan standar peraturan yang berlaku, sebab masih banyak APAR yang tidak dilengkapi dengan tanda letak APAR.

Tanda letak APAR masih sangat kurang, jika ada tanda letak APAR itu pun masih sangat sedikit dan tanda sudah pudar susah untuk dibaca. APAR yang berat kotor tidak melebihi 18 $\mathrm{kg}$ harus dipasang sehingga ujung atas APAR tingginya tidak lebih dari 1,5 meter di atas lantai. APAR dengan berat lebih dari $18 \mathrm{~kg}$ (kecuali jenis yang dilengkapi roda) harus dipasang tidak lebih dari 1 meter di atas lantai. Dalam hal apapun pada peletakan APAR harus ada jarak antara APAR satu dan lainnya dengan lantai tidak kurang dari $10 \mathrm{~cm}$. Antara alat pemadam api satu dengan lainnya atau kelompok satu dengan lainnya tidak boleh melebihi 15 meter, kecuali ditetapkan lain oleh pegawai pengawas atau ahli keselamatan kerja.

\section{Pemeliharaan dan Kondisi Fisik Alat Pemadam Api Ringan (APAR)}

Menurut Permenakertrans No: PER.04/MEN/1980 tentang syarat-syarat pema-sangan dan Pemeliharaan Alat Pemadam Api Ringan pasal 11 ayat 1 bahwa seluruh APAR wajib di cek minimal 2 kali dalam setahun, ialah pengecekan pada jangka 6 (enam) bulan dan pemeriksaan dalam jangka 12 (dua belas) bulan. Berdasarkan hasil observasi dan wawancara didapatkan hasil bahwa hampir setiap bulan dilakukan pemeliharaan APAR. Hal ini bertujuan untuk mengetahui kondisi dan isi dari setiap APAR agar selalu siap ketika akan digunakan ketika terjadi kebakaran.

Beberapa unit APAR yang terdapat di gedung kantor BPBD Provinsi Sumatera Utara memiliki kondisi yang baik, tidak ditemukan APAR dengan kondisi fisik berkarat, dan semua safety pin terpasang. Pada setiap APAR terdapat rambu yang menunjukan bahwa APAR tersedia dan siap pakai. Berdasarkan Permen PU No. 26 Tahun 2008 Tentang Persyaratan Teknis Sistem Proteksi Kebakaran pada Bangunan Gedung dan Lingkungan, menjelaskan tentang standarisasi untuk masalah perlindungan kebakaran terhadap bangunan gedung dan lingkungan. Dijelaskan juga tentang syarat teknis untuk alat pemadam api ringan (APAR) pada bab V yang berisi tentang Sistem Proteksi Kebakaran Aktif.

Peraturan Menteri Tenaga Kerja dan Transmigrasi No : Per.04/Men/1980 juga menjelaskan tentang Syarat-Syarat Pemasangan dan Pemeliharan Alat Pemadam Api Ringan yang 
berisikan tentang ketentuan standarisasi APAR di Indonesia yang harus di laksanakan. Dijelaskan juga pada peraturan di Amerika tentang APAR yang tertulis di NFPA 10 tahun 2002 tentang standar alat kebakaran portabel yang menjelaskan tentang standar-standar yang diharuskan untuk pemasangan dan pemeliharaan tentang APAR.

Setiap alat pemadam api ringan harus diperiksa 2 kali dalam setahun, yaitu pemeriksaan dalam 6 bulan dan pemeriksaan dalam jangka 12 bulan. Cacat pada alat perlengkapan pemadam api ringan yang ditemui waktu pemeriksaan, harus segera diperbaiki atau alat tersebut segera diperbaiki atau alat tersebut segera diganti dengan yang tidak cacat. Petunjuk cara-cara pemakaian alat pemadam api ringan harus dapat dibaca dengan jelas. Frekuensi pemeriksaan APAR sangat penting untuk pemeliharaan APAR. dimana frekuensi pemeriksaan sesuai dengan standar, maka akan diketahui kondisi APAR di lapangan apakah masih dalam kondisi baik atau tidak.

\section{KESIMPULAN}

APAR (Alat Pemadam Api Ringan) adalah alat yang digunakan untuk memadamkan api atau mengendalikan kebakaran. Ketersediaan APAR sangat diperlukan untuk mencegah kebakaran karena tidak semua tempat dapat menjangkau air dengan mudah dan memiliki air dalam jumlah yang cukup untuk memadamkan api,selain itu jika sudah terjadi kebakaran dengan api besar akan lebih sulit dipadamkan dan harus meminta bantuan pada petugas pemadam kebakaran padahal untuk menuju tempat terjadinya kebakaran juga perlu memakan waktu dan dikhawatirkan jika api tidak segera ditangani akan lebih cepat merambat dan membakar lebih banyak benda disekitarnya. Untuk itu di perlukan evaluasi pemasangan APAR di Kantor BPBD Provinsi Sumatera Utara untuk memudahkan penanganan jika terjadi kebakaran di area gedung kantor.

\section{DAFTAR REFERENSI}

Firdani, L, Ekawati, \& Kurniawan, B. (2014). Analisis Penerapan Alat Pemadam Api Ringan (APAR) Di PT. X Pekalongan. Jurnal Kesehatan Masyarakat (E-Journal). Vol.2, No.5.

Hambyah, R. F. (2016). Evaluasi Pemasangan APAR Dalam Sistem Tanggap Darurat Kebakaran Di Gedung Bedah RSUD Dr. Soetomo Surabaya. The Indonesian Journal Of Occupational Safety And Health. Vol.5, No.1: 41-50.

Hamid, Mariska. (2019). Evaluasi Apar Dan Hidran Sebagai Upaya Penanggulangan Kebakaran Di PT X. MTPH Journal, Vol. 3, No.2.

Hidayat, F.A., \& Partiwi, S.G. (2015). Perencanaan Emergency Response Plan (ERP) Dan Alat Pemadam Api Ringan (APAR) Pada Gedung Research Centre ITS. JURNAL TEKNIK ITS. Vol.4, No.1.

Karimah, M., Kurniawan, B., \& Suroto. (2016). Analisis Upaya Penanggulangan Kebakaran Di Gedung Bougenville Rumah Sakit Telogorejo Semarang. Jurnal Kesehatan Masyarakat (E-Journal). Vol.4, No.4.

Keputusan Menteri Negara Pekerjaan Umum Republik Indonesia Nomor : 11/KPTS/2000 Tanggal 1 Maret 2000 Tentang Ketentuan Teknis Manajemen Penanggulangan Kebakaran di Perkotaan.

Notoatmodjo, S. (2010). Metodologi Penelitian Kesehatan. Jakarta: Rineka Cipta.

Panja, H. (2020). Penerapan Sarana Alat Pemadam Api Ringan Di Pusat Perbelanjaan Mall. HIGEIA. Vol.4, No.2: 281-283.

PERATURAN MENTERI TENAGA KERJA DAN TRANSMIGRASI NOMOR PER04/MEN/1980 TENTANG SYARAT-SYARAT PEMASANGAN DAN PEMELIHARAAN ALAT PEMADAM API RINGAN. 
Pradipta, Yoga. (2016). Identifikasi Kebutuhan Alat Pemadam Api Ringan Di RSP Universitas Brawijaya Malang. The Indonesian Journal Of Occupational Safety And Health, Vol.5, No.1.

Pratama, Agus. (2016). Perancangan Sarana Penyelamat Diri Dan Kebutuhan APAR Pada Darurat Kebakaran Di Kantor Kesehatan Pelabuhan Kelas II Balikpapan. The Indonesian Journal Of Occupational Safety And Health. Vol.5, No.1:21-30.

Rini Irani. (2009). Upaya Pencegahan Dan Penanggulangan Bahaya Kebakaran Sebagai Antisipasi Dini Terhadap Bahaya Kebakaran Di Pusdiklat Migas Cepu. Program Diploma III Hiperkes Dan Keselamatan Kerja Fakultas Kedokteran Universitas Sebelas Maret Surakarta.

Uni Pratama Tarigan, Irwan Budiman. (2021). Implementasi Metode Lean Service dan 5 S untuk Meningkatkan Efisiensi Waktu Pelayanan di Dinas Pencegah dan Pemadam Kebakaran Kota Medan. 